\title{
Journal of Family Planning and Reproductive Health Care
}

\author{
The Journal of the Faculty of Family Planning and Reproductive Health Care of the \\ Royal College of Obstetricians and Gynaecologists
}

Registered Charity No. 1019969

www.ffprhc.org.uk

Registered Company No. 2804213

The Journal of Family Planning and Reproductive Health Care is a peer-reviewed journal that aims to improve reproductive and sexual health nationally and internationally by disseminating highest quality research and information that is relevant to clinical care, service delivery, training and education in the field of contraception and reproductive/sexual health.

\section{Members of the Editorial Board}

Editor-in-Chief:

Associate Editors:
Fran Reader, FRCOG, MFFP

Beccy Hobbs, MFHom, MIPM

Beccy Hobbs, MFHom, MIPM

Nick Manassiev, MRCOG, MFFP
Advisory Editor:

Trainee Editor:

Statistical Advisors:
Gill Wakley, MFFP, MIPM Kate Weaver, MB ChB, BSc Jill Mollison, PhD, CStat Julie Simpson, PhD, CStat

Journal Administrator: Jacquie Silcott, Journal of Family Planning and Reproductive Health Care, RCOG, 27 Sussex Place, Regent's Park, London NW1 4RG, UK. Tel: +44 (0) 207724 5681. Fax: +44 (0) 207723 5333. E-mail: journal@ffprhc.org.uk. Website: www.ffprhc.org.uk

Managing Editor: Janie Foote, 11 Graydon Avenue, Chichester, West Sussex PO19 8RF, UK. Tel/Fax: +44 (0) 1243538106. E-mail: editor@pmh.uk.com

Sales Manager: Sarah Monger, PMH Publications, PO Box 100, Chichester, West Sussex PO18 8HD, UK. Tel: +44 (0) 1243576444. Fax: +44 (0) 1243 576456. E-mail: adsales@pmh.uk.com

\section{Members of the Editorial Advisory Board}

Faculty Officer Representative: Editor-in-Chief:

Associate Editor Representative:

Faculty Council Representative:

Service Advisors:

Academic Advisors:

Genitourinary Medicine Advisor: Elizabeth Carlin, FRCP, DFFP
General Practice Advisor: Lindsay Smith, MD, FRCGP

Ethical Advisor: $\quad$ Susan Carr, MFFP, MPhil

Statistical Advisor: $\quad$ Jill Mollison, PhD, CStat

International Advisors: $\quad$ Ruzva Bhathena, MD, FRCOG

Lindsay Edouard, FRCOG, MFFP

Petrus Steyn, FCOG(SA), MPhil

Edith Weisberg, FACSHP, FRANZCOG

Nurse Advisor (co-opted): Linda Hayes, MA, RN

SARC Representative: $\quad$ Rosemary Kirkman, FRCOG, MFFP

\section{FROM THE EDITORS}

From the retiring Editor-in-Chief

Charles Lamb described retirement as 'walking about' not 'to and from'. With this in mind I am delighted to retire to the role of Editor Emeritus for the rest of this volume and pass the 'to and from' into the able hands of Anne Szarewski as the newly appointed Editor-in-Chief.

However, before I go I have an important apology to make to all readers. In April I talked about slipping up on the banana skin of the downside of sexual expression - this month it is the banana skin of the downside of publishing proofreading with your brain not engaged. In April we transferred to a new printer and were delighted with the prompt dispatch of the Journal to readers ahead of schedule. However, we all missed the fact that the pagination for the April issue was identical to that of the January issue (in that the pagination of both issues began at page 1)! We have raised this matter with the National Library of Medicine (NLM) and received reassurance that it is not a problem for MEDLINE and PubMed as long as we point out the error to readers - see the Errata on page 159. When referencing papers it is always helpful to give the issue number as well as the volume number. It is essential to do this when referencing a paper from one or other of the two affected issues.

On a brighter note, this issue sees inclusion of the CEU's statement on Cerazette. This is a first for the Journal and the CEU and it provides a service to readers that we feel sure will be appreciated. The CEU will continue to publish statements on new products on the Faculty website at www.ffprhc.org.uk as well as in the Journal.

Finally, I have enjoyed my years as Editor-in-Chief. I have learnt something new with the challenges of every issue. My thanks go to everyone who has helped to produce the Journal over the last 5 years: authors, peer reviewers, the Editorial Advisory Board and Editorial Board, our publishers $\mathrm{PMH}$, printers past and present, and Ingenta who have given the Journal an electronic presence. My good wishes for the future go to Anne and her new venture.

Fran Reader, FRCOG, MFFP

Retiring Editor-in-Chief, Journal of Family Planning and Reproductive Health Care 
From the Future Editor-in-Chief

The new Millennium has seen the Journal go from strength to strength, and I'd like to pay tribute to Fran Reader, who has worked so hard to bring it where it is today. It has changed its name, from the British Journal of Family Planning, to the Journal of Family Planning and Reproductive Health Care, in order to reflect a wider scope and readership. It is included on MEDLINE and has a circulation in excess of 11000 a year. Fran has developed an editorial team, moved the Journal to a commercial publisher and into electronic publication.

There are several areas that I see as being important for the further evolution of the Journal. My major task in the long term is to acquire a citation index for the Journal. Journals with a high 'impact factor' (e.g. New England Journal of Medicine, Lancet) are those to which researchers choose to send their best papers. I want our Journal to be up there.
However, I am also conscious that there is a continual conflict between academia and the 'real world'. I hope that we can publish papers and articles that, while academically excellent, will still be relevant to the everyday clinic setting.

I would like to encourage a greater exchange of ideas internationally. The growth of our 'electronic' Journal will facilitate a wider readership and I hope will result in more submissions from outside the UK. I am also interested in the views of our clients and allied health professionals. I hope we can provide a forum for discussion that will allow us to gain insights into each other's views and experiences, and enhance safe and effective contraceptive and reproductive health practices.

Anne Szarewski, PhD, MFFP

Future Editor-in-Chief, Journal of Family Planning and Reproductive Health Care

\section{Faces behind the Journal of Family Planning and Reproductive Health Care}

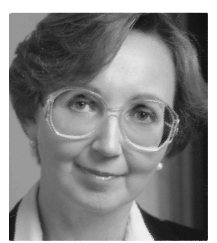

Anne Szarewski, MBBS, DRCOG, PhD, MFFP (Editor-in-Chief, August 2003 onwards)

Anne Szarewski has two concurrent posts: Clinical Consultant in the Department of Epidemiology, Mathematics and Statistics at Cancer Research UK, London and Senior Clinical Medical Officer in Family Planning at the Margaret Pyke Centre, London. She has worked in family planning and reproductive health care for 17 years, with special interests in hormonal contraception and cervical screening/colposcopy.

Prior to taking up the Editorship, she has been a Member Representative on the Council of the Faculty of Family Planning and Reproductive Health Care and a member of the Editorial Advisory Board of the Journal. She has a long-standing interest in education (both of health professionals and the lay public), has been Convenor of the Critical Reading Question for the MFFP, and a peer reviewer for several journals. Anne has numerous publications, both scientific and more general, including books on contraception and cervical smears aimed primarily at the lay reader. Her research publications include studies of cytology screening techniques, the effects of smoking cessation on cervical lesions and a number of studies assessing aspects of HPV testing.

Kate Weaver, MB ChB, BSc (Trainee Editor, January-July 2003) Kate Weaver is a Staff Grade Doctor in Family Planning and Reproductive Health Care at Dean Terrace Family Planning and Well Woman Clinic in Edinburgh. She has special interests in colposcopy and in contraceptive implants and is widely involved in research, education and publishing. She has recently completed the FFPRHC's Career Grade Training and passed her MFFP examinations.

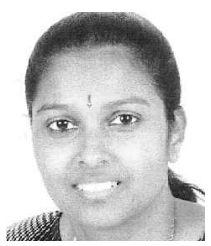

P S Arunakumari, MD, MRCOG (Trainee Editor, August 2003 onwards)

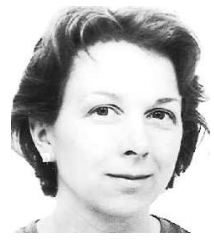

P S Arunakumari is a specialist registrar in obstetrics and gynaecology. Her field of special interest is reproductive health care and, in particular, contraception. She holds postgraduate degrees from India (MD) and the UK (MRCOG). Her MD dissertation was on a cervical screening programme in rural India. She is currently in the final stages of completing her MFFP.

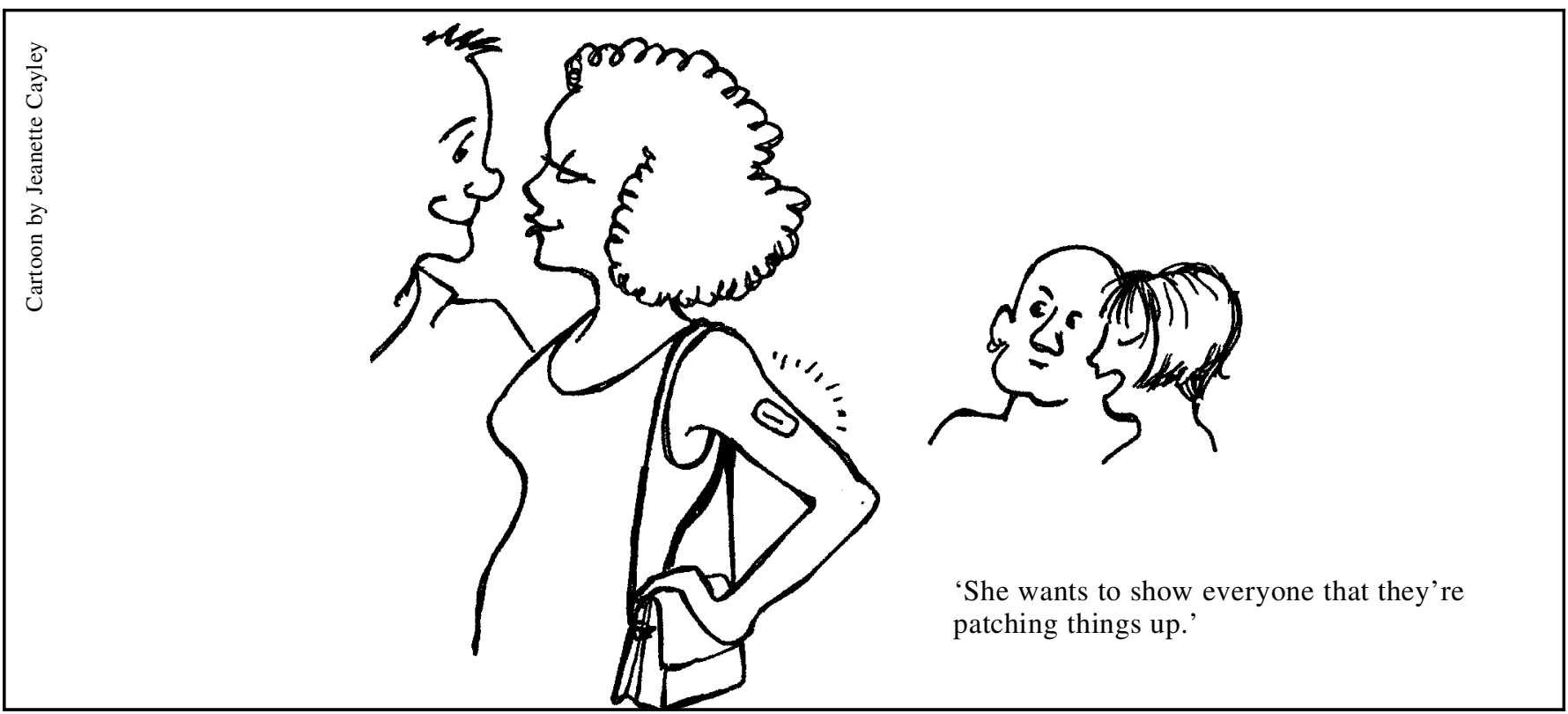

